\title{
2. MID-ATLANTIC RIDGE SITE 395 REVISITED: OPERATIONS AND EXPLANATORY NOTES1
}

\author{
Shipboard Scientific Parties ${ }^{2}$
}

\section{HOLE 395A}

Date reoccupied: 19 March 1981 (1100)

Date departed: 31 March 1981 (1600)

Time on hole: 12 days, $5 \mathrm{hr}$.

Position: $22^{\circ} 45.35^{\prime} \mathrm{N} ; 46^{\circ} 04.90^{\prime} \mathrm{W}$

Water depth (sea level; corrected m, echo sounding): 4483

Water depth (rig floor; corrected m, echo sounding): 4493

Bottom of casing (rig floor; $\mathrm{m}$, drill pipe): $\mathbf{4 6 0 5}$

Bottom of open hole (rig floor; $\mathrm{m}$, drill pipe): 5102

\begin{tabular}{|c|c|c|}
\hline Tools run & $\begin{array}{l}\text { Sub-bottom } \\
\text { interval (m) }\end{array}$ & $\begin{array}{l}\text { Data } \\
\text { quality }\end{array}$ \\
\hline Temperature probe; water sampler & $29-105 ; 105$ & None; good \\
\hline Temperature probe; water sampler & $105-219 ; 219$ & Poor; none \\
\hline Temperature probe; water sampler & $2-248 ; 248$ & None; good \\
\hline Temperature probe; water sampler & $371-400 ; 400$ & Good; good \\
\hline Temperature probe; water sampler & $514-543 ; 543$ & Fair; good \\
\hline Temperature log & $0-609$ & Good \\
\hline Temperature log (repeat) & $72-609$ & Good \\
\hline $\begin{array}{l}\text { Density; caliper; natural gamma } \\
\quad \log \end{array}$ & $112-609$ & $\begin{array}{l}\text { Fair; good; } \\
\text { good }\end{array}$ \\
\hline $\begin{array}{l}\text { Velocity; caliper; natural gamma } \\
\quad \log \end{array}$ & $112-609$ & $\begin{array}{l}\text { Fair; none; } \\
\text { none }\end{array}$ \\
\hline $\begin{array}{l}\text { Laterolog; porosity; natural } \\
\text { gamma log }\end{array}$ & $112-609$ & $\begin{array}{l}\text { None; poor; } \\
\text { poor }\end{array}$ \\
\hline $\begin{array}{l}\text { Laterolog; porosity; natural } \\
\text { gamma log }\end{array}$ & $112-609$ & $\begin{array}{l}\text { Good; poor; } \\
\text { poor }\end{array}$ \\
\hline $\begin{array}{l}\text { Soviet magnetometer: field inten- } \\
\text { sity log }\end{array}$ & $112-609$ & Good \\
\hline $\begin{array}{l}\text { Soviet magnetometer: susceptibil- } \\
\text { ity log }\end{array}$ & $112-609$ & Good \\
\hline Borehole televiewer log & $112-609$ & Fair \\
\hline $\begin{array}{l}\text { Packer: pulse test; water sampler; } \\
\text { hydrofracture }\end{array}$ & 582 & $\begin{array}{l}\text { Good; fair; } \\
\text { none }\end{array}$ \\
\hline Packer: shut-in test; pulse test & 179 & Good; none \\
\hline Packer: pulse test & 182 & None \\
\hline $\begin{array}{l}\text { DARPA seismometer: seismic; } \\
\text { temperature }\end{array}$ & 609 & Good; good \\
\hline
\end{tabular}

\footnotetext{
${ }^{1}$ Hyndman, R. D., Salisbury, M. H., et al., Init. Repts. DSDP, 78B: Washington (U.S. Govt, Printing Service).

2 Glomar Challenger: Roy D. Hyndman (Co-Chief Scientist), Pacific Geoscience Centre, Department of Energy, Mines and Resources, Sidney, B.C. Canada; Matthew H. Salisbury (Co-Chief Scientist), Scripps Institution of Oceanography, La Jolla, California; Alan Ballard, Naval Ocean Research and Development Activity, NSTL Station, Mississippi; Keir Becker, Scripps Institute of Oceanography, La Jolla, California; Jerome Denis, Laboratoire de Geochemie des Eaux, Université de Paris, Paris, France; Stephen Hickman, U.S. Geological Survey, Menlo Park, California; Marcus Langseth, Lamont-Doherty Geological Observatory, Celu Columbia Universty, Palisades, New Yrk; Mark A. Mathew, Los Alabos Scientific Laboratory, University of California, Los Alamos, New Mexico; Vladislav Nechoroshkov, Institute of Geophysics, Sverdlovsk, U.S.S.R.; Vladimir Ponomarev, Institute of Geophysics, Sverdlovsk, U.S.S.R.; Joseph Svitek, U.S. Geological Survey, Menlo Park, California.

Lynch: Randy Jacobson (Chief Scientist), Naval Ocean Research and Development Activity, NSTL Station, Mississippi; Anne Boyd, Naval Ocean Research and Development Activ. ity, NSTL Station, Mississippi; Douglas McGowan, Marine Science Institute, University of Texas at Austin, Galveston, Texas.
}

Principal results: Hole 395A was reentered five years after drilling was initially done at this site for the purpose of conducting logging and downhole experiments in the upper oceanic crust and to conduct a deployment test for the emplacement of a long-term recording seismometer in the Pacific in 1982. Although the bottom $55 \mathrm{~m}$ of the hole was blocked, a 497-m interval from the bottom of the casing to the top of the cavings (112-609 m sub-bottom) was still open and in good condition.

Although the hole was enlarged, the deep investigation (latero$\log$ ) and borehole wall tools (density, caliper) worked fairly well throughout the hole, and the velocity tool worked where the hole was to gauge. Using these logs and the magnetometer and televiewer results, it was possible to confirm and refine the basement stratigraphy described by the Leg 45 scientific party. The logged interval contains one massive basalt unit, extending from 89 to $99 \mathrm{~m}$ subbasement, with an apparent bulk density of $2.8 \mathrm{~g} / \mathrm{cm}^{3}$ and a compressional wave velocity of 5 to $6 \mathrm{~km} / \mathrm{s}$. This interval is bracketed above and below (79-89 $\mathrm{m}$ and $99-114 \mathrm{~m}$ sub-basement) by thin units displaying a high magnetic susceptibility and containing serpentinized peridotite. The remainder of the section consists of pillow and flow basalts with a variable formation density of 2.5 to $2.8 \mathrm{~g} / \mathrm{cm}^{3}$ (corrected), a velocity of up to $5.5 \mathrm{~km} / \mathrm{s}$, and resistivities of 20 to $1000 \mathrm{ohm}-\mathrm{m}$ that increase dramatically near the base of the hole. Downhole logging with the Soviet magnetometer showed distinct magnetic field reversals at $170 \mathrm{~m}$ and $475 \mathrm{~m}$ sub-basement, with the middle unit being reversely polarized and the upper and lower units being normally polarized.

Temperature measurements conducted shortly after reentry indicate that the hole was isothermal at $2.5^{\circ} \mathrm{C}$ to about $250 \mathrm{~m}$ subbottom. Below this depth, the temperature increased slowly, but at an accelerating rate with depth, to $18^{\circ} \mathrm{C}$ at a depth of about $605 \mathrm{~m}$. Between $605 \mathrm{~m}$ and the top of the cavings, the temperature rose abruptly to $22^{\circ} \mathrm{C}$, apparently in a short section of drilling mud left in the hole by Leg 45 . With the exception of one sample collected near the base of the hole ( $543 \mathrm{~m}$ ), which shows $\mathrm{Mg}$ depletion, water samples from all levels of the hole are indistinguishable from local bottom water. This observation and the temperature data suggest drawdown to a depth of at least $250 \mathrm{~m}$, diffuse flow into the formation between $250 \mathrm{~m}$ and a maximum depth of $543 \mathrm{~m}$, and stagnation at greater depths. These results are consistent with packer tests that show that the permeability near the base of the hole is extremely low (3-9 $\mu$ Darcies below $582 \mathrm{~m}$ ) but that the upper part of the section must be highly permeable.

The DARPA seismometer was successfully deployed in the bottom of the hole and then recovered, demonstrating the feasibility of emplacing large, delicate observatories in the seafloor. In addition to obtaining excellent records during a two-ship refraction experiment with the Lynch, the seismometer recorded microseisms and several earthquakes.

\section{HOLE 395B}

Date occupied: 26 March 1981 (0745)

Date departed: 26 March 1981 (1230)

Time on hole: 5 hours

Position: $22^{\circ} 45.35^{\prime} \mathrm{N} ; 46^{\circ} 04.90^{\prime} \mathrm{W}$

Water depth (sea level; corrected m, echo-sounding): 4483

Water depth (rig floor; corrected m, echo-sounding): 4493

Bottom felt (rig floor; m, drill pipe): 4493 


\section{Penetration (m): 70}

Number of cores: 0

Total of length of cored section (m): 0

Principal results: Hole 395B was washed to a sub-bottom depth of 70 $\mathrm{m}$ about $100 \mathrm{~m}$ northwest of Hole $395 \mathrm{~A}$ in order to measure the temperature and collect a pore water sample in the sediments near the basement. The results were ambiguous because of possible seawater contamination.

\section{OPERATIONS}

The Glomar Challenger departed San Juan, Puerto Rico at 1130 on March 14, 1981. After checking the operation of the positioning system and thrusters outside the harbor, a course was set for Site 395 midway between the tracks taken by the Challenger to and from the Site on Leg 45 (Fig. 1). Because of excellent weather, the ship was able to make 10 knots until slowing to $6 \mathrm{knots}$ at $0920 \mathrm{hr}$. on March 19 for the initial approach. Using a combination of satellite navigation, dead reckoning, and bottom and sub-bottom profiles, the ship was navigated over the site (Figs. 2 and 3) and a $16-\mathrm{kHz}$ long-life beacon dropped at $1138 \mathrm{hr}$. The course was confirmed for another $15 \mathrm{~min}$., then the underway geophysical gear was pulled in and the ship was returned to the site and positioned over the beacon.

After the ship was stabilized over the beacon, the bottom hole assembly was made up and the pipe lowering was started at $1215 \mathrm{hr}$., the pipe reaching the bottom $7 \mathrm{hr}$. later at $1920 \mathrm{hr}$. Satellite fixes received during the pipe lowering indicated that the beacon had been dropped within a ship's length of the reentry cone. The precision depth recorder water depth was $4483 \mathrm{~m}, 2 \mathrm{~m}$ less than the reading on Leg 45 .

The reentry of Hole 395A was delayed until $1034 \mathrm{hr}$. on March 20 because of several tool failures. One of the transducers on the first tool was damaged either on deck or when it seated, and the second tool failed while going down the pipe. The third tool performed flawlessly, however, allowing reentry after only an hour and a half of scanning along an expanding square search pattern. After the tool was brought to the surface, reentry was confirmed by lowering a full stand of pipe into the hole. One stand was then withdrawn so that the temperature structure in the water below the maximum penetration of the stand $(45 \mathrm{~m})$ would not be disturbed by pumping down the heat-flow tool.

The downhole experiment program began at 1305 on March 20, when a heat-flow probe-pore-water sampler with a shortened probe was started down the pipe at a pumping rate of 5 strokes per min. (spm). The tool latched in at about $1345 \mathrm{hr}$., after which temperatures were measured for $3 \mathrm{~min}$. at each of seven intervals at a $10-\mathrm{m}$ spacing in the casing. The pipe was lowered a joint at a time at a rate of 1 joint $/ \mathrm{min}$. without pumping. After the last temperature measurement, a preset timer opened the water sampler for $7 \mathrm{~min}$. at a level $7 \mathrm{~m}$ above the casing shoe at a depth of $4598 \mathrm{~m}$ below the rig floor $(105 \mathrm{~m}$ sub-bottom). The bit was then raised $10 \mathrm{~m}$ and the tool returned to the surface on the sand line after a 5-min. stop at the mud line for thermistor calibration. When

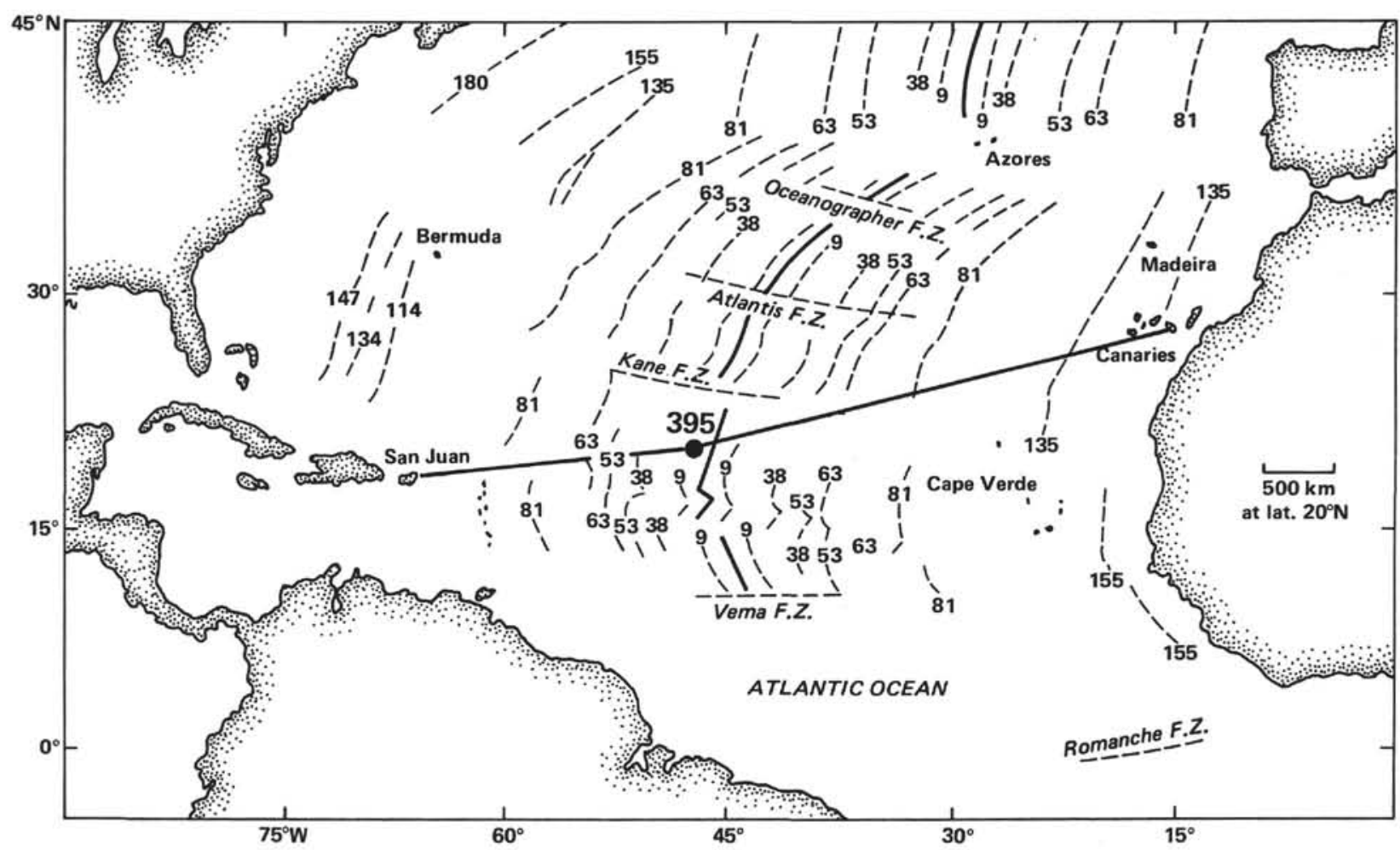

Figure 1. Map showing location of Site 395 and Leg 78B ship's track. (Dashed lines show age of crust in millions of years deduced from magnetic anomalies.) 


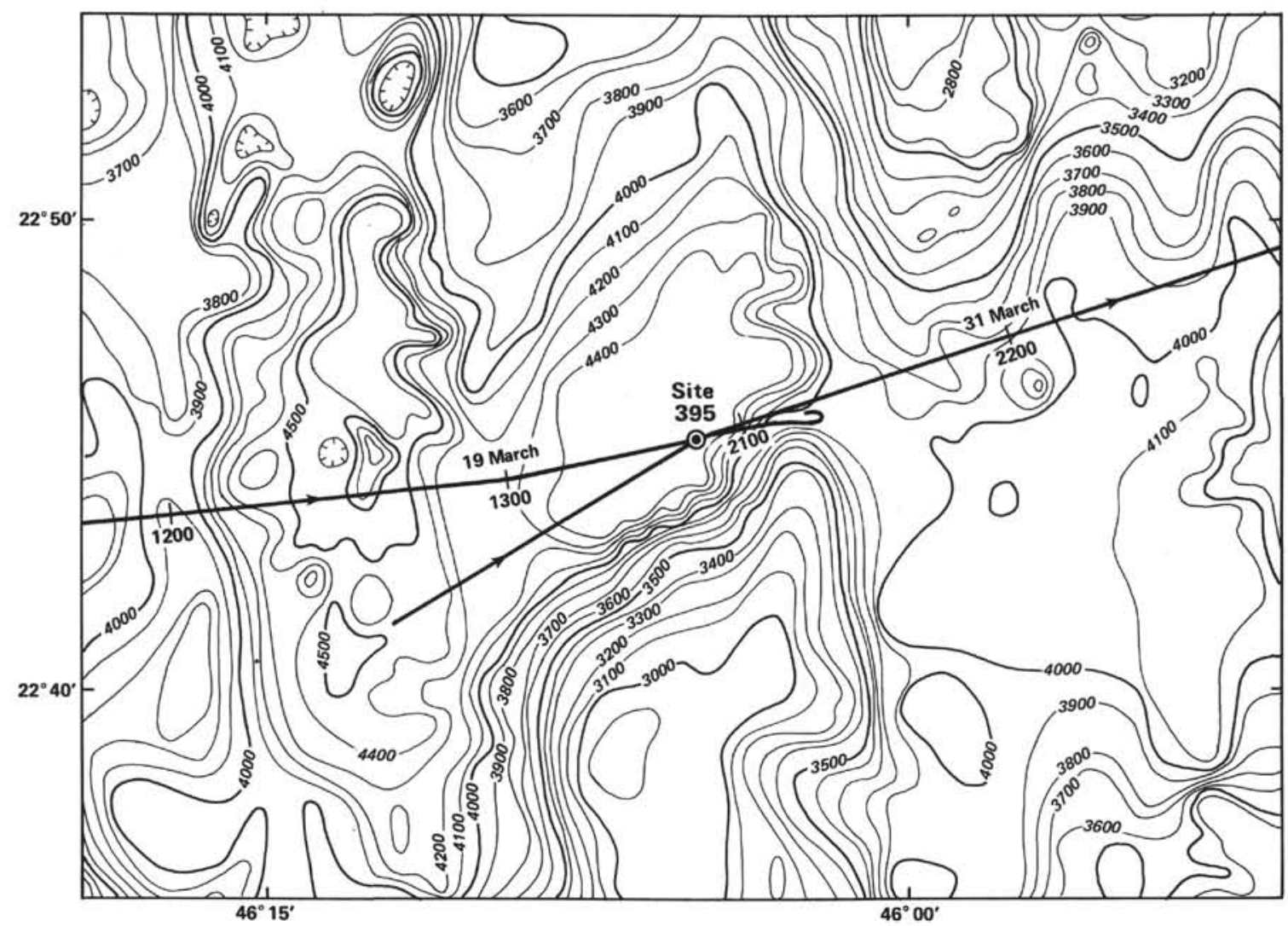

Figure 2. Ship track of Glomar Challenger approaching and departing Site 395 on Leg 78B. (Depths are shown in meters.)

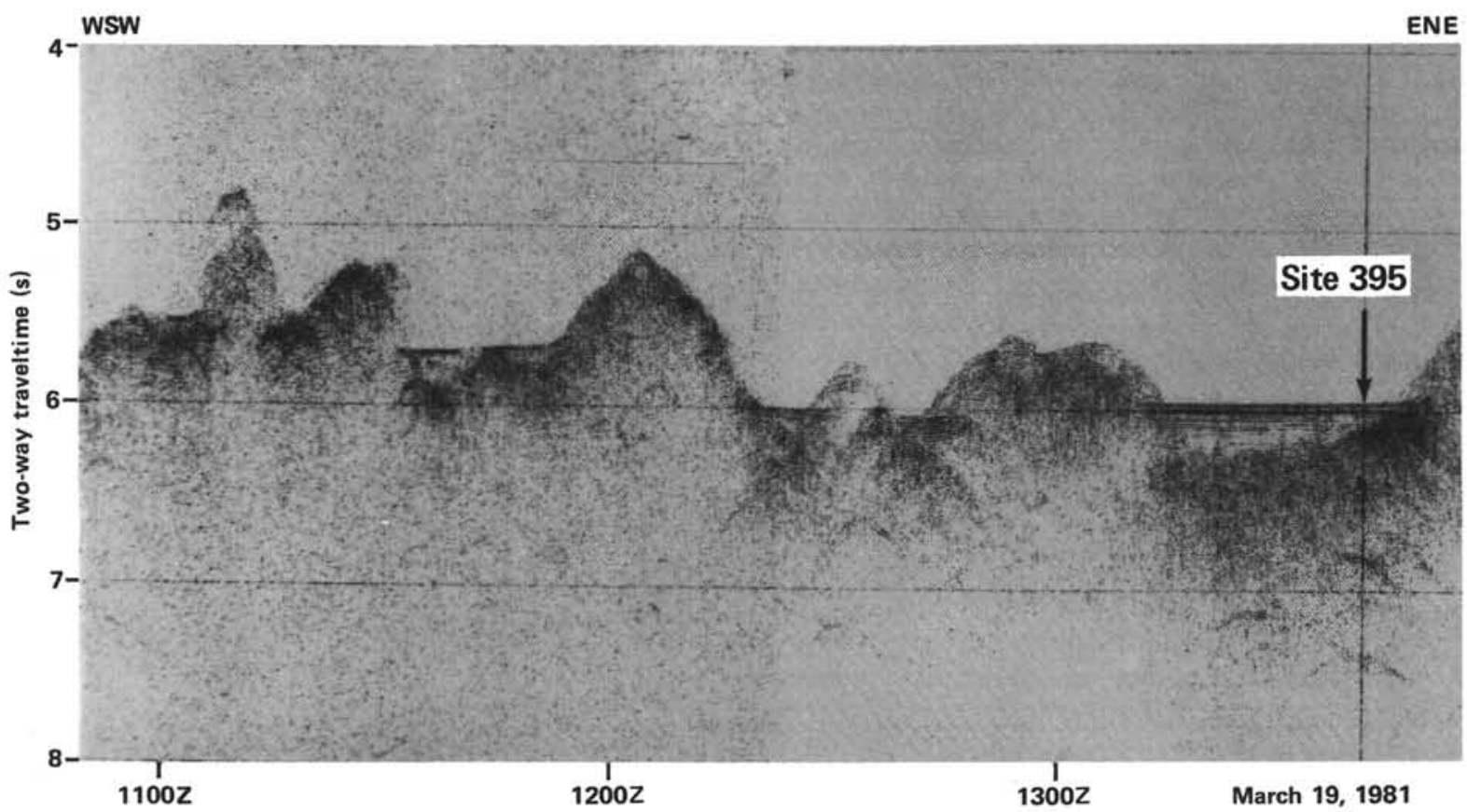

Figure 3. Glomar Challenger air-gun record approaching Site 395 on Leg 78B.

the tool was recovered at $1515 \mathrm{hr}$., it was found that the water sampler had operated properly but that the heatflow unit had malfunctioned.

A second heat flow-pore water run was made between 1600 and $1715 \mathrm{hr}$. while lowering the pipe a further
$100 \mathrm{~m}$ with similar recording and sampling stations. As on the previous run, the tool was pumped down at $5 \mathrm{spm}$. On this run, an electrical short resulted in invalid temperature readings, and a valve failure caused the water sample to be lost. 
Because we thought that the electronics failures associated with the first two runs might have been caused by impact, the third run was made by lowering the tool on the sand line without pumping. After the tool latched in, temperatures were recorded at eight depths while the pipe was lowered in 10-m increments, and a water sample was taken at the deepest station $(4741 \mathrm{~m}$ below the rig floor). While the tool was being recovered, the sand line parted $1200 \mathrm{~m}$ above the tool and the tool and sand line had to be fished from the pipe. When the tool was finally received on deck at 0620 on March 21, it was found that the water sampler had functioned properly but that the heat-flow tool had again malfunctioned.

On the fourth run, conducted between 0718 and 0916 hr. on March 21, the tool was again lowered on the sand line with $5 \mathrm{spm}$ pumping. Four temperature measurements, each of 3-min. duration, were made at stations located 4864, 4874, 4883 and $4893 \mathrm{~m}$ below the rig floor. As before, a water sample was taken at the deepest station. The temperature measurements and the water sampling were both successful.

The fifth and last run was conducted between 1032 and $1244 \mathrm{hr}$. on March 21. The tool was lowered on the sand line without pumping. Four stations, located 5007, 5017,5026 and $5036 \mathrm{~m}$ below the rig floor, were occupied, and a water sample was taken at the deepest station. After it was verified that this run had been successful, the bit was lowered until a solid blockage was encountered at $5102.4 \mathrm{~m}$. Considering the history of hole problems below this depth during drilling, it was decided that no attempt would be made to clean the hole to its original total depth of $5157 \mathrm{~m}$. The bit was released and the end of the drill pipe pulled up to $4587 \mathrm{~m}$ within the casing in preparation for logging.

After rigging the logging sheaves, at $1600 \mathrm{hr}$. on March 21 we started down a combined Gearhart-Owen gammagamma density-2-arm caliper-natural gamma-high resolution temperature log while pumping at $15 \mathrm{spm}$. The pump was shut off and the temperature log recording begun at a depth of $4440 \mathrm{~m}$ below the rig floor, continuing downhole from 1823 to $1944 \mathrm{hr}$. to the blockage at about $5100 \mathrm{~m}$. The bottom $20 \mathrm{~m}$ of the hole were relogged to determine the thermal stability of a high temperature layer found at the base of the hole. Because Hole 395A was filled with mud on Leg 45, it was thought that the temperature in this layer might represent the equilibrium temperature preserved in undisturbed mud in the bottom of the hole.

After the temperature log was completed, the density-caliper-natural gamma tools were checked by logging up to $5025 \mathrm{~m}$. The hole was then logged up from the bottom of the hole to the casing from 2036 to $2134 \mathrm{hr}$. and arrived on deck at about midnight. Although the density and caliper logs were satisfactory, the natural gamma log appeared to have malfunctioned. It was later decided to be good, however.

A sonic velocity-2-arm caliper-natural gamma tool was started down the pipe shortly after midnight on March 22 while the rate of pumping was maintained at $15 \mathrm{spm}$. After the tool reached the bottom, a short test section was again run up the hole to $5020 \mathrm{~m}$. The tool was then lowered again and the hole logged up to a depth of $4605 \mathrm{~m}$ (the casing shoe) between 0346 and $0428 \mathrm{hr}$. The tool was then brought to the surface, reaching the rig floor at 0700 on March 22 . The sonic log had operated well, but the data was poor except near the bottom of the hole because of extensive hole enlargement, and the natural gamma log appeared to be dead. The caliper functioned mechanically (i.e., it centralized the tool) but it did not record.

The third logging run was made with a combined laterolog-neutron porosity-natural gamma tool. It was pumped down slowly at a rate of $15 \mathrm{spm}$ starting at $0700 \mathrm{hr}$. on March 22 and arriving at the bottom at 0920 hr. A short test section was run up the hole to $5015 \mathrm{~m}$, the hole was then logged up to the casing between 0937 and $0958 \mathrm{hr}$., and then the tool returned to the surface at about 1130 . The neutron porosity tool had malfunctioned, the gamma log was poor, and the laterolog had failed because of a short in the connecting bridle.

The bridle was repaired, and the combined laterologneutron porosity-natural gamma tool was started down the pipe again at about noon at a pumping rate of $15 \mathrm{spm}$. After a short test section was run up to $5000 \mathrm{~m}$, the tool was relowered and the hole logged up to the casing between 1358 and $1415 \mathrm{hr}$., the tool reaching the deck at 1530 . None of the tools functioned well except the laterolog.

After the logging program was completed (for a summary, see Fig. 4 and Table 1), the Soviet downhole magnetometer was started down the pipe at $1600 \mathrm{hr}$. at a pumping rate of $15 \mathrm{spm}$. From the bottom of the casing, the tool descent was slowed to $7 \mathrm{~m} / \mathrm{min}$. and the vertical component of the magnetic field, $H_{z}$, was successfully logged to the bottom of the hole. The log was repeated up the hole to the casing. An attempt was then made to measure the horizontal component of the field, $H_{x}$, but the alignment of the tool depends on the inclination of the hole and the hole was so nearly vertical that the tool turned continuously. The attempt was thus abandoned and the tool was returned to the surface by about midnight.

The magnetic susceptibility tool was then attached and lowered with the magnetometer. When it reached the casing shoe, lowering was again slowed to $7 \mathrm{~m} / \mathrm{min}$. and logging was done almost to the base of the hole. The bottom was not touched in order to avoid damaging the ceramic pressure case of the tool. The horizontal field component recording was attempted again to see if the tool would work in this section of the hole but without success. The tool was then brought to the surface, reaching the deck by 0530 on March 23 .

Because the quality of the temperature measurements made in the hole with the self-contained temperature probe was questionable and the first temperature log had been conducted after the water column had been somewhat disturbed by pumping, it was decided to repeat the temperature log so that the trend toward thermal equilibrium could be established before the hole was cleaned for the televiewer and packer experiments. The temperature tool was first calibrated in an ice bath and then started down the pipe at $0530 \mathrm{hr}$. The hole was success- 


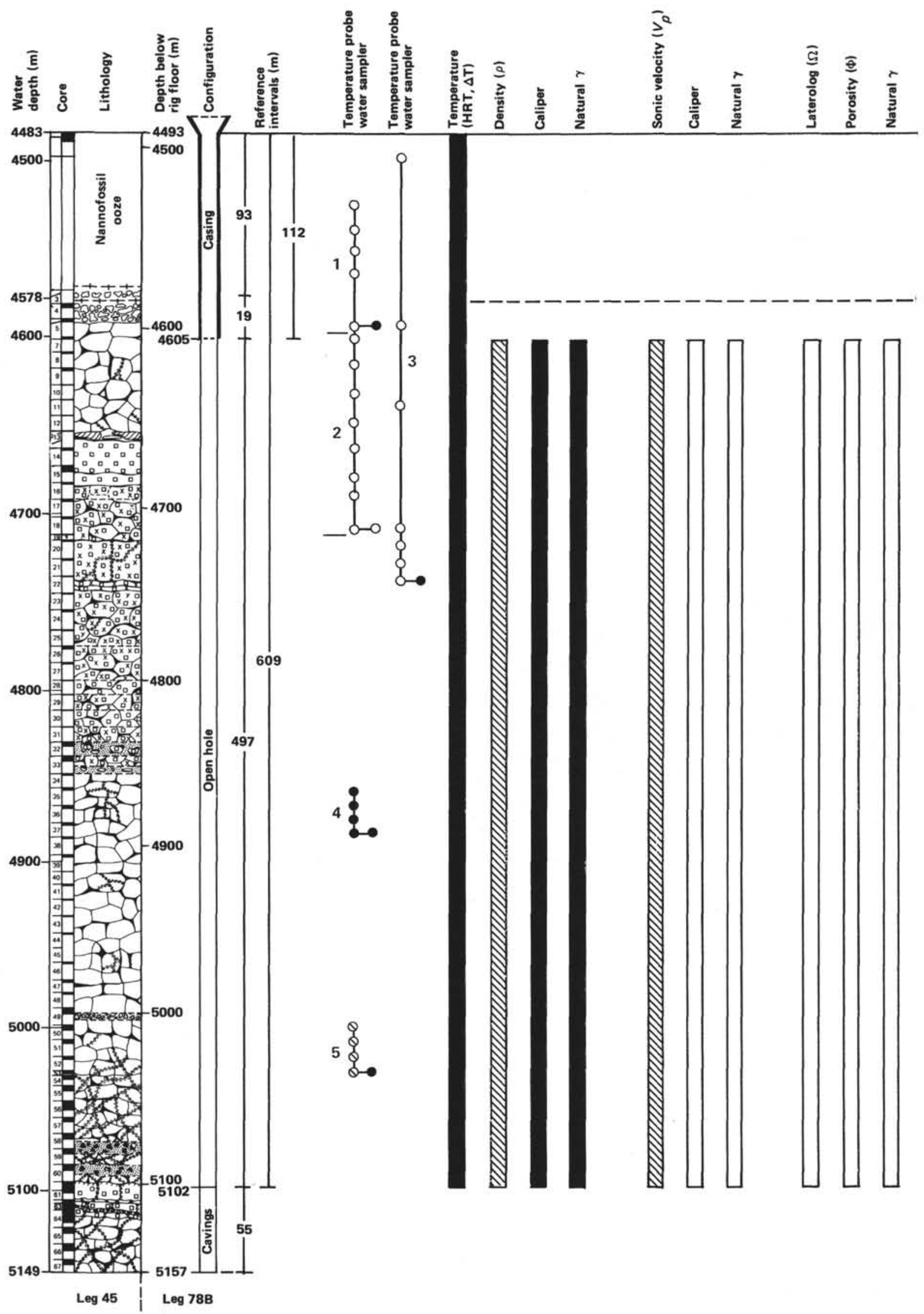

Figure 4. Hole 395A operations summary showing instrument deployment levels and data quality. The numbers 1 to 5 on the temperature probe water sampler plots refer to the downhole runs. (Lithologic column from Natland [1979].) 

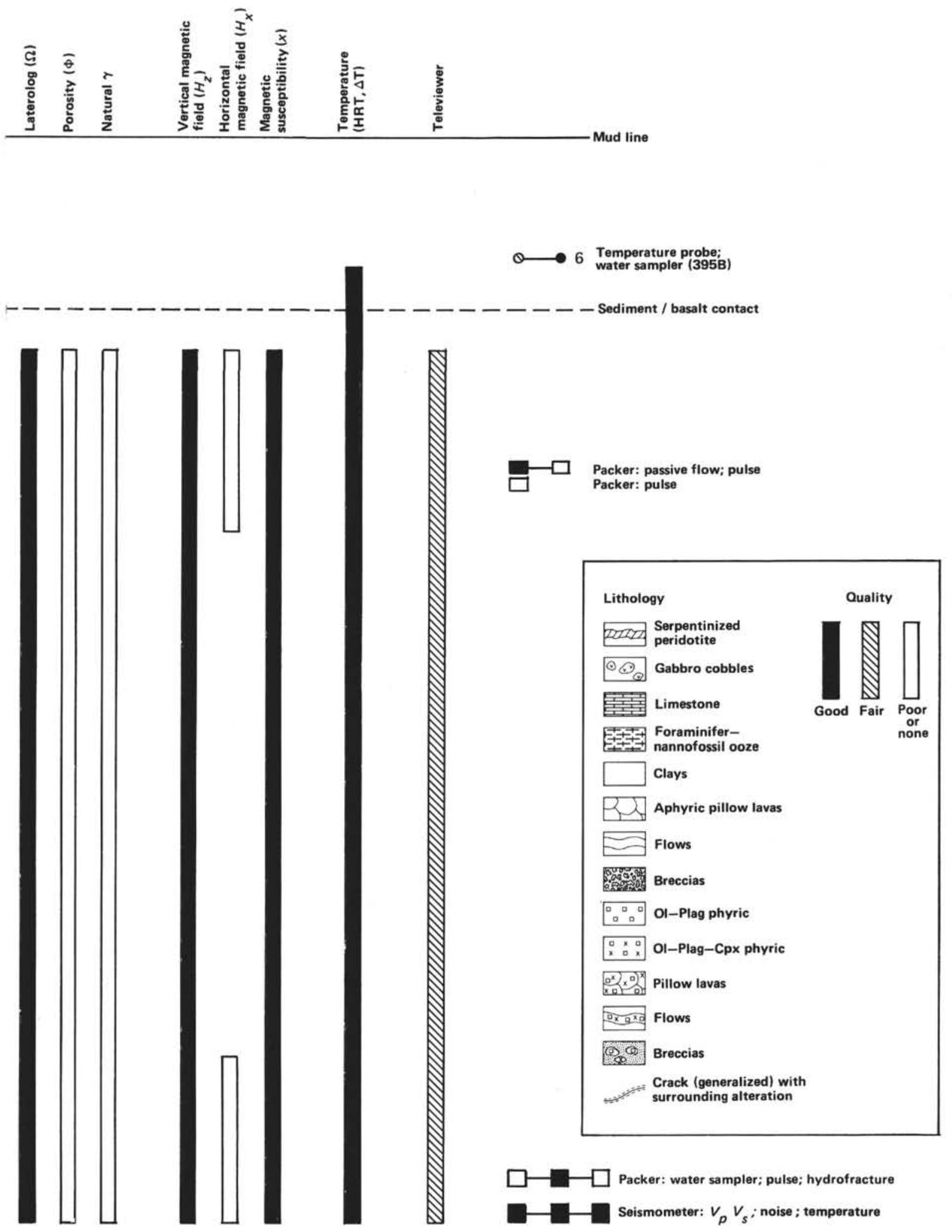

Figure 4. (Continued.) 
Table 1. Leg 78B downhole operations summary, Site 395.

\begin{tabular}{|c|c|c|c|c|c|c|c|c|}
\hline Run & Date & Time & $\begin{array}{l}\text { Depth } \\
\text { below } \\
\text { rig floor } \\
\text { (m) }\end{array}$ & $\begin{array}{l}\text { Sub- } \\
\text { bottom } \\
\text { depth } \\
\text { (m) }\end{array}$ & $\begin{array}{l}\text { Logging } \\
\text { direction }\end{array}$ & Tool/test & $\begin{array}{c}\text { Data } \\
\text { quality }\end{array}$ & Remarks \\
\hline
\end{tabular}

Temperature probe-water sampler

$\begin{array}{rrrrrr}1 & 3 / 20 / 81 & 1300-1512 & 4522-4598 & 29-105 & \text { Down } \\ 2 & 3 / 20 / 81 & 1557-1715 & 4598-4712 & 105-219 & \text { Down } \\ 3 & 3 / 20 / 81 & 1957-2400 & 4495-4741 & 2-248 & \text { Down } \\ 4 & 3 / 21 / 81 & 0000-0620 & & & \\ 5 & 3 / 21 / 81 & 0718-0916 & 4864-4893 & 371-400 & \text { Down } \\ & 3 / 21 / 81 & 1032-1244 & 5007-5036 & 514-543 & \text { Down }\end{array}$

Downhole logging

$\begin{array}{lrrrrr}1 & 3 / 21 / 81 & 1600-2400 & 4400-T D & 0-609 & \begin{array}{l}\text { Down } \\ \text { Up }\end{array} \\ & 3 / 21 / 81 & 2018-2400 & \text { Casing-TD } & 112-609 & \\ 2 & 3 / 22 / 81 & 0000-0700 & \text { Casing-TD } & 112-609 & \text { Up } \\ 3 & 3 / 22 / 81 & 0700-1130 & \text { Casing-TD } & 112-609 & \text { Up } \\ 4 & 3 / 22 / 81 & 1200-1530 & \text { Casing-TD } & 112-609 & \text { Up }\end{array}$

Soviet magnetometer

$\begin{array}{llll}1 & 3 / 22 / 81 & 1530-2400 & \\ 2 & 3 / 23 / 81 & 0000-0030 & \\ 3 & 3 / 23 / 81 & 0030-0500 & \\ 4 & 3 / 23 / 81 & 0500-0530\end{array}$

$\begin{array}{lll}\text { Casing-TD } & 112-609 & \text { Down, up } \\ \text { Casing-4700 } & 112-207 & \text { Down, up } \\ \text { Casing-TD } & 112-609 & \text { Down } \\ \text { TD-5000 } & 507-609 & \text { Up }\end{array}$

Downhole logging

$$
5 \quad 3 / 23 / 81
$$

0530-1130

4565-TD

72-609 Down

Borehole televiewer

acker

$1 \quad 3 / 24 / 81 \quad 1100-2400 \quad 5075$

$2 \quad 3 / 25 / 81 \quad 1700-2400 \quad 4672$

$3 / 26 / 81 \quad 0000-0800 \quad 4672$

Temperature probe-water sampler (Hole 395B)

$$
6 \quad 3 / 26 / 81 \quad 0853-1230 \quad 4563
$$

DARPA seismometer

$\begin{array}{lll}3 / 27 / 81 & 0000-2400 & \text { TD } \\ 3 / 28 / 81 & 0000-2400 \\ 3 / 29 / 81 & 0000-2400 \\ 3 / 30 / 81 & 0000-0445\end{array}$

609

Temperature
HRT, $\Delta \mathrm{T}$

HRT, $\Delta \mathrm{T}$
$\rho$
Caliper
$\gamma$
$V_{\mathrm{p}}$
Caliper
$\gamma$
Laterolog
$\phi$
$\gamma$
Laterolog
$\phi$
$\gamma$

Temperature probe Water sampler Temperature probe Water sampler Temperature probe Water sampler Temperature probe Water sampler Temperature probe Water sampler

$H_{z}$
$H_{x}$
$x$
$H_{x}$

Good

Good

Stationary

$V_{p}, V_{s}$
Noise

- $\quad$ Recorder malfunctioned.

Good Sampled at $4598 \mathrm{~m}$.

Poor Thermistor cable shorted.

- Sampler valve malfunctioned.

- Recorder malfunctioned.

Good Sampled at $4741 \mathrm{~m}$.

Good

Good Sampled at $4893 \mathrm{~m}$.

Fair Recorder unstable.

Good Sampled at $5036 \mathrm{~m}$.

Good

Fair

Good

Good

Fair

-

Poor

Poor
Poor

Good

Poor

Poor

Good near base of hole.

Centralized tool but no data recorded. Tool malfunctioned.

Short in bridle.

Hole oversized.

Hole oversized.

Good Calibrated in ice bath.

Fair Heavy swell; incomplete motor sweep.

Televiewer

Water sampler

Fair

Partially contaminated with surface water.

Pulse test

Hydrofracture

Stationary Passive flow

Stationary Pulse test

Good

Good

No fracture at $2200 \mathrm{psi}$.

$-$

Packer failed.

Fair

Good

Temperature probe

Good

Good

Shooting conducted by Lynch.

Packer

$3 \quad 3 / 30 / 81 \quad 0445-2400 \quad 4675$ $3 / 31 / 81 \quad 0000-0545$

Note: $\mathrm{HRT}=$ high resolution temperature; $\Delta \mathrm{T}=$ differential temperature; $\rho=$ gamma-gamma density; $\gamma=$ natural gamma ray; $V_{p}=$ compressional wave velosity; $V_{S}=$ shear wave velocity; $\phi=$ neutron porosity; $H_{z}=$ magnetic field strength, vertical component; $H_{x}=$ magnetic field strength, horizontal component; $x=$ magnetic susceptibility. TD $=$ total depth. 
fully logged from $4565 \mathrm{~m}$ to the bottom of the hole between 0811 and $0915 \mathrm{hr}$., after which the tool was returned to the surface by $1130 \mathrm{hr}$.

After the temperature logging tool was recovered, the pipe was lowered to the bottom and seawater was circulated for an hour to flush out the mud left in the hole on Leg 45 (traces were detected in the water samples). The pipe was then raised back into the casing.

Starting at $1400 \mathrm{hr}$., the televiewer was run to the bottom of the casing. Although the tool had functioned well on deck, in the hole the scanning motor only ran at one-third the correct speed, which amplified the already serious problem of ship heave. Because the performance would still allow evaluation of the walls of the hole for packer seating and geologic reconstruction, the hole was logged with the tool as it was. The tool arrived back on deck at $0300 \mathrm{hr}$. on March 24 . The data were only fair, because of the motor problem and because the data were scrambled by heave-induced stretching and overprinting during the run and individual features such as pillows and cracks could only rarely be discerned. However, massive basalt sections suitable for setting the packer could be clearly distinguished from pillow basalts on the basis of reflectivity differences.

After the televiewer was recovered and the logging sheaves removed, the pipe was brought to the surface to install a Lynes packer in order to conduct permeability and flow tests. At $1100 \mathrm{hr}$. the pipe was run back down, reaching the seafloor by $1830 \mathrm{hr}$. When the EDO reentry scanning tool reached the bottom of the pipe, it was found that two stands had inadvertently been left out of the pipe string. It was thus necessary to recover the reentry tool, add two stands of pipe, and lower the tool again. When the tool was back on bottom at $0133 \mathrm{hr}$. on March 25, scanning was resumed and the hole reentered by $0334 \mathrm{hr}$.

Once reentry was confirmed, the packer was lowered to $5075 \mathrm{~m}$ in order to take a large-volume water sample and to run the first pressure test. The sampler go-devil was sent down at $0700 \mathrm{hr}$. and reached the packer at about $0800 \mathrm{hr}$., after which the packer was inflated, the hole sealed, the water sample taken from the lowermost portion of the hole, and the go-devil retrieved, the latter arriving on deck with the water sample at $1030 \mathrm{hr}$. When the water sampler was opened downhole, the formation below the packer was subjected to a large, negative pressure pulse from the water filling the sample chamber. The record obtained by the Kuster Ltd. pressure recorder in the go-devil showed very slow pressure equilibration, indicating that the permeability of the formation near the bottom of the hole was extremely low. This fact was confirmed between 1030 and $1700 \mathrm{hr}$. when the safety go-devil was sent down, the packer reinflated, and a conventional pressure pulse test run using the ship's pumps. Because the packer seal was excellent and the formation was very impermeable, a hydrofracture test to $2200 \mathrm{psi}$ was conducted at the same level in order to determine the in situ stress. Because no fracture was produced at this pressure and higher pressures might have damaged the packer, the go-devil was retrieved and the packer raised to $4672 \mathrm{~m}$, the intention being to return to the base of the hole at the end of the packer experiments to complete the test at higher pressures.

With the packer at $4672 \mathrm{~m}$, two attempts with the safety go-devil were required before the tool was finally inflated at $2140 \mathrm{hr}$. On the first attempt the overpressure shear plug had sheared prematurely. With the packer inflated, the hole below the packer was isolated and the aquifer pressure was passively recorded until midnight in order to monitor the formation pressure. After this test, a second series of pulse tests was attempted, but the packer could not be kept inflated. When it was found that the packer could not be reinflated even after resetting and refurbishing the go-devil a third time, it was concluded that the packer had ruptured, and the packer experiment was terminated at $0600 \mathrm{hr}$. on March 26.

Because there was insufficient time to run the pipe to the surface, refurbish the packer, lower the tool, and repeat the experiment before the scheduled start of the DARPA/NORDA downhole seismometer experiment and because the large-scale resistivity experiment was postponed until after the seismometer test to ensure that the logging cable was not damaged and could be used for reentry, it was decided to pull out of the hole, conduct heat flow measurements in the sediments next to the hole, and return the pipe to the surface.

Before the pipe was pulled completely out of the hole, instrumentation designed to measure pipe stress was inserted into the drill string and tested between 0700 and $0745 \mathrm{hr}$. to calibrate the equipment and monitor the stress under moderate loads. Although the equipment worked on deck, it apparently failed after it was lowered into position.

After the instrumented pipe was removed from the string, the pipe was pulled above the mudline, offset $101 \mathrm{~m}$ to the northwest (58 m south and $67 \mathrm{~m}$ west of the beacon) and a new hole (Hole 395B) started for heat-flow measurements. The bit was washed in to a depth of $4563 \mathrm{~m}$ below the rig floor, after which the heat-flow-pore-water sampler was lowered on the sand line at 0853 and recovered at $1230 \mathrm{hr}$. Although the tool functional properly, the data may have been degraded by seawater contamination.

Once the tool was on deck, we started pulling the pipe immediately. The last stages of the pipe recovery went slowly because of the need to magnaflux the bottomhole assembly, and the pipe was on deck by $2315 \mathrm{hr}$. on March 26. With the arrival of the Lynch earlier that afternoon (at $1500 \mathrm{hr}$.) to set out current meters, deploy ocean bottom seismographs, and conduct shooting, the stage was set for the DARPA/NORDA downhole seismometer experiment.

After the power sub and swivel were magnafluxed, the DARPA instrument package and deployment equipment were set up under nearly ideal sea state conditions between 0130 and $1045 \mathrm{hr}$. on March 27 . The deployment went smoothly, with the instrument recording a maximum acceleration of only $4.2 \mathrm{~g}$ during handling. As soon as the instrument package was assembled and the electromechanical (EM) cable connected, the pipe and cable were lowered together, the instrument reaching the seafloor at about $1900 \mathrm{hr}$. The EDO tool was 
then lowered and reentry achieved at $2357 \mathrm{hr}$. after $51 \mathrm{~min}$. of scanning. The maximum acceleration experienced by the instrument package during reentry was $6 \mathrm{~g}$.

After the reentry tool was retrieved, the borehole instrument package was released from its carriage and lowered to the bottom of the hole by $0715 \mathrm{hr}$. on March 28 . Once it was confirmed that the instrument was in the bottom of the hole, the EM cable was released and the pipe was raised to the surface, reaching the rig floor by $2145 \mathrm{hr}$. There was no indication of entanglement between the drill string and the cable. The ship was then moved $915 \mathrm{~m}$ WSW while cable was payed out, both to reduce ship's noise in the vicinity of the seismometer and to provide an unobstructed shooting line over the hole for the Lynch. During the move, the ship's propulsion system was shut down for $15 \mathrm{~min}$. to establish the background noise level in the borehole.

Although the Lynch had arrived two days earlier and had begun setting out current meters almost immediately, the OBSs could not be deployed until the last minute because they could only be set to record for $24 \mathrm{hr}$. Three OBSs were accordingly set $1.1 \mathrm{~km}$ north, $1.8 \mathrm{~km}$ west, and $1.8 \mathrm{~km}$ southwest of the cone between $2300 \mathrm{hr}$. on March 28 and $0300 \mathrm{hr}$. on March 29. The Lynch then steamed to a position $44.4 \mathrm{~km}$ northeast of the Challenger, exploding a series of successively larger charges between 0625 and $0700 \mathrm{hr}$. while enroute in order to calibrate the instrument. After the noise level and sensitivity had been established, the Lynch shot a split refraction line over the cone along a heading of $049^{\circ}$ relative to the Challenger to a position $74.1 \mathrm{~km}$ to the southwest (Fig. 5). The vessel then steamed ESE for about $36 \mathrm{~km}$, turned north and shot until it reached the southwest line, at which point it turned northeast and reshot the original line back to the hole. After reaching the hole, the Lynch changed to a course of $280^{\circ}$ and shot along a line extending $29.6 \mathrm{~km}$ to the west. The shooting was terminated at $1100 \mathrm{hr}$., after which the Lynch returned to the vicinity of the Challenger and picked up her OBSs. The shooting completed, the Challenger returned to its former position over the hole and pulled up the tool by 0400 hr. on March 30.

Preliminary examination of the data during the course of the shooting experiment indicated that the noise level in the hole was very low and that the refraction data were of excellent quality. Temperature measurements recorded at the same time from a thermistor near the surface of the instrument package were in agreement with the highest temperatures observed near the base of the hole during logging.

After the DARPA seismometer package was secured, the packer and the bottom-hole assembly were made up and the pipe was lowered to the seafloor for the last time. The pipe reached the bottom at $1645 \mathrm{hr}$., after which the reentry tool was lowered and the hole reentered by $1944 \mathrm{hr}$. After the EDO tool was retrieved, the packer was lowered to a depth of $4675 \mathrm{~m}$. When the safety go- devil was dropped and the tool was inflated, it held weight and pressure briefly but then lost pressure and would not reinflate. When the tool still would not inflate after the go-devil was redressed and rerun, it was concluded that the packer had ruptured under abuse from the hammering of the bumper subs in rising seas, and the experiment was terminated. Because the large-scale resistivity experiment could not be run (the cables were found to be corroded) and deteriorating weather precluded further heat-flow runs, it was decided to abandon the hole at 0545 on March 31. After a brief pause until 0815 to test the downhole bit motion indicator (DBMI), the pipe was brought to the surface and the vessel secured for steaming by 1600 .

While pulling the pipe, the ship had been allowed to drift off station to facilitate pipe handling (Fig. 2). After the Challenger got underway, she crossed over the beacon at $1749 \mathrm{hr}$. local time and set a course for Las Palmas, leaving the Lynch behind to pick up the ocean bottom seismographs and return to Fort Lauderdale. By the time the Challenger made port in Las Palmas in the early morning on April 8, 1981, it was clear that through good luck (the weather was exceptional), good seamanship (the beacon was dropped within $120 \mathrm{~m}$ of the cone) and the expertise of the ships' officers and staff, nearly all of the objectives of the leg had been accomplished.

\section{Explanatory Notes}

Because Site 395 was reoccupied on Leg 78B for the purpose of conducting downhole geophysical experiments, no coring was conducted during the leg. The core descriptions and petrology referred to throughout the course of the ensuing chapters are from Melson, Rabinowitz, et al. (1979).

While reoccupying the site and reentering Hole 395A, we noted a series of depth discrepancies between the Leg 45 and Leg 78B results. Both sets of depths are shown in Fig. 4. To facilitate direct comparison of the logging and geophysical results obtained on Leg 78B with the petrologic column determined on Leg 45, the depths reported throughout this volume (except this Operations chapter) have been converted to Leg 45 sub-bottom or sub-basement depths.

\section{REFERENCES}

Hussong, D. M., Fryer, P. B., Tuthill, J. D., and Wipperman, L. K., 1979. The geological and geophysical setting near DSDP Site 395, North Atlantic Ocean. In Melson, W. G., Rabinowitz, P. D., et al., Init. Repts. DSDP, 45: Washington (U.S. Govt. Printing Office), 23-27.

Melson, W. G., Rabinowitz, P. D., et al., 1979. Init. Repts. DSDP, 45: Washington (U.S. Govt. Printing Office).

Natland, J. H., 1979. Comparison of chemical and magnetic stratigraphy of basement rocks at DSDP Sites 332 and 395 . In Melson, W. G., Rabinowitz, P. D., et al., Init. Repts. DSDP, 45: Washington (U.S. Govt. Printing Office), 657-677.

Date of Initial Receipt: July 26, 1983

Date of Acceptance: August 17, 1983 


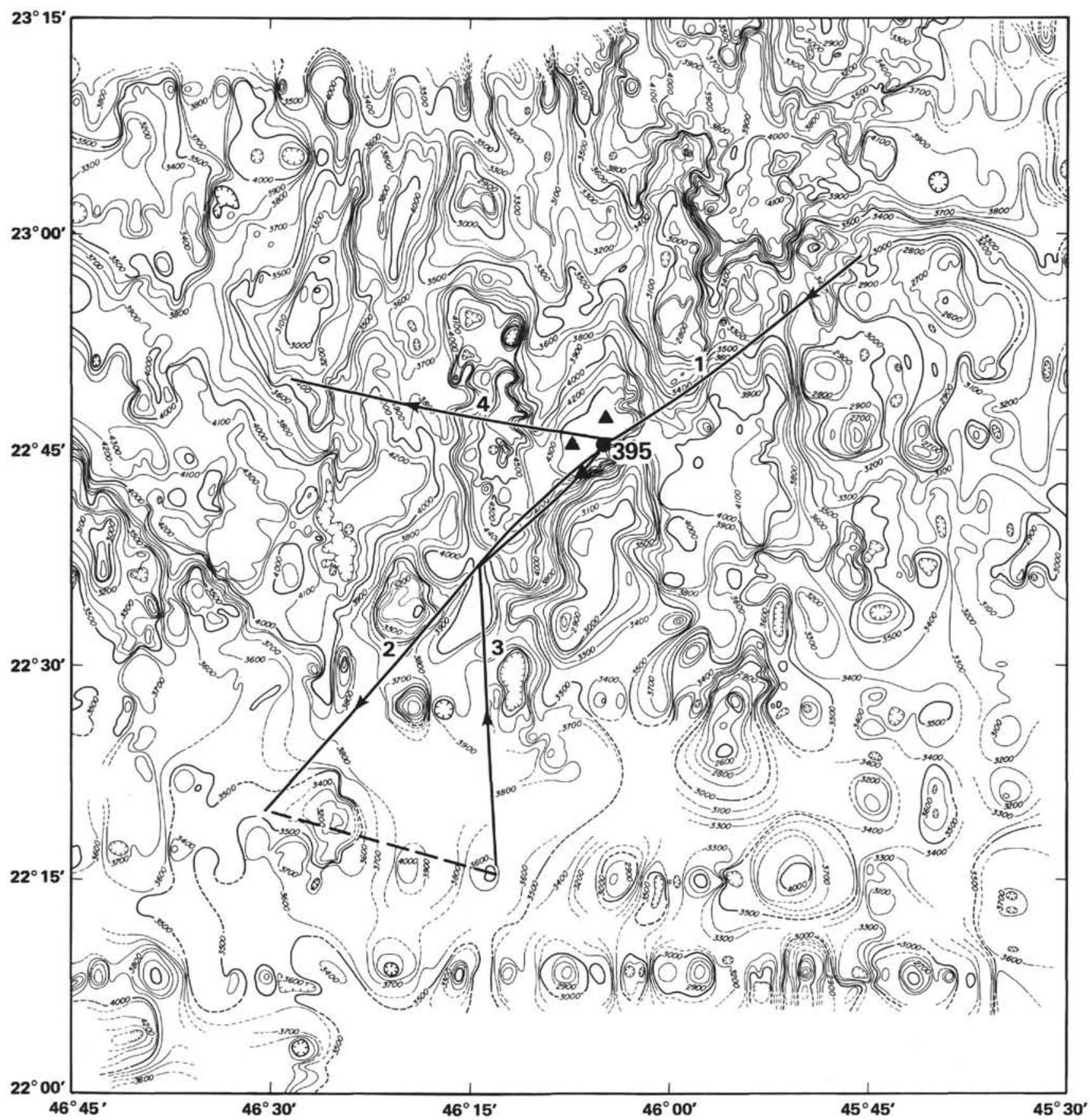

Figure 5. Lynch shot lines in the vicinity of Hole 395A. (Triangles indicate OBS locations. Map from Hussong et al. [1979]. Depths are in corrected meters.) 